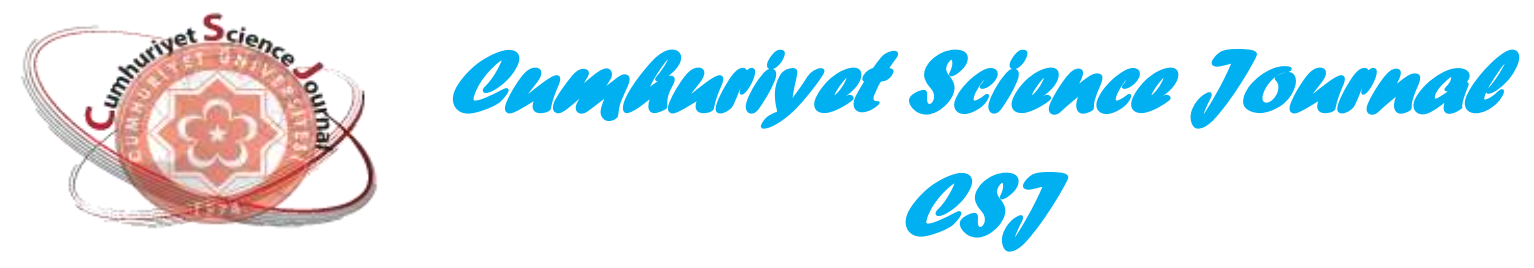

\title{
The Investigation of Mechanical Properties of the Flash Welded Different Steel Bars
}

\author{
Ahmet AKKUŞ \\ Cumhuriyet University, Faculty of Engineering, Department of Mechanical Engineering / TURKEY \\ Received: 28.06.2017; Accepted: 17.10.2017 \\ http://dx.doi.org/10.17776/csj.349400
}

\begin{abstract}
In this study, three type steel bars were selected as experimental specimens. The steel types are S235JR (St37), S355JR (St52), AISI 304 stainless steel. Experimental parameters are material type and weld current. The specimens which have $Ø 24 \times 200 \mathrm{~mm}$ dimensions flash welded both each other and different steel bars as using three weld currents. After the welding operations, the welded specimens were cooled at open - air conditions and their diameters were dropped by using a lathe machine so that the tensile tests can be applied to them. Micro Vickers hardness tests and tensile tests were performed each center of the welded specimens and around the weld zone. According to results, it was not seen that change in welding current has a direct effect on hardness and the highest hardness value was seen in St52-St52 sample. It was seen generaly increase in welding current negatively effected breaking strenght and least effected welded samples by tensile strenght welding current were St37-St37, AISI304-AISI304. The results are given as Figures and discussed.
\end{abstract}

Keywords: Flash welding, different metals, hardness, tensile strength.

\section{Yakma Alın Kaynağı ile Birleştirilmiş Farkı Çelik Barların Mekanik Özelliklerinin Araştırılması}

Özet: Bu çalışmada malzeme olarak S235JR (St37), S355JR (St52), AISI 304 Paslanmaz Çelik seçilmiştir. Bu malzemeler Ø24 x $200 \mathrm{~mm}$ boyutlarında 36 adet deney çubuğu olarak hazırlanmıştır. Deney parametreleri olarak malzeme tipi ve kaynak akımı seçilmiştir. $24 \mathrm{~mm}$ çap ve $200 \mathrm{~mm}$. uzunluğundaki deney numuneleri, hem kendi aralarında hem de farklı malzemeler birbiriyle kaynak olacak şekilde üç farklı kaynak akımında birleştirilmiş̧ir. Kaynak işlemlerinden sonra numuneler açık havada soğutulmuş ve torna tezgahında çapları çekme deneyine uygun hale getirilmiştir. Her numuneye çekme testi uygulanmış ve kaynak bölgelerinin micro vikers sertlik ölçümleri yapılmıştır. Sertlik ölçümü sonuçlarına göre, kaynak akımının sertlik üzerinde doğrudan bir etkiye sahip olmadığı görülmüştür. En yüksek sertlik değeri ise St52 - St52 kaynaklı numunede tespit edilmiştir. Kaynak akımındaki artışın çekme dayanımı üzerinden genellikle olumsuz bir etkiye sahip olduğu görülmüsşür. Kaynak akımının en az etkilediği kombinasyon ise St37 - St37 ve AISI304 - AISI 304 malzeme kombinasyonlarıdır. Sonuçlar tablolar ve grafikler halinde verilmiş ve irdelenmiştir.

Anahtar Kelimeler: Yakma alın kaynağı, farklı malzemeler, sertlik, çekme dayanımı.

\section{INTRODUCTION}

There are seriously problems in the joining by using melting welding methods, expecially in metals which have different material properties. Flash welding is widely used to forging different or same composition metallic pieces. Different kind of metals with different melting and thermal conductivity make flash welding one of the the best joining methods. The flash welding is a kind of 
electrical resistance welding porcesses, it covers heating, pressing and building up porcesses.

In this study, three type steel bars were selected as experimental specimens. The steel types are (St37), S355JR (St52), AISI 304 stainless steel. Experimental parameters are material type and weld current. The specimens which have Ø24 x 200 $\mathrm{mm}$ dimensions flash welded both each other and different steel bars as usingh three weld currents. After the welding operations, the welded specimens were cooled at open - air conditions and their diameters were dropped by using a lathe machine so that the tensile tests can be applied to them. Micro Vickers hardness tests were performed each center of the welded specimens and around the weld zone.

Flash welding process has a wide study file. Some reseachers studied on metallic specimens which have both same and diferent steel materials by using flash welding joining process [1, 13].

\section{MATERIALS AND METHOD}

In this study, S235JR (St37), S355JR (St52), AISI304 stainless steels were chosen. These materials were prepared in $\varnothing 240 \times 200 \mathrm{~mm}$ dimensions as 36 test bars. These test bars were welded at 851 amperes, 967 amperes, 1102 amperes in flash weld machine. Welded test bars were left for natural cooling at $+5{ }^{\circ} \mathrm{C},+10{ }^{\circ} \mathrm{C}$ workshop temperatures. There was no cooling with water or oil. $10 \mathrm{~mm}$ shortening occured because of accumulation at the connection point of $\varnothing 24 \times 200$ $\mathrm{m}: \mathrm{m}$ test bars. With the condition of weld point of test bars stay in the axis one end of test bars shortened $95 \mathrm{~mm}$ and converted into $200 \mathrm{~m}$. The spectrometric analysis of these 3 materials were made. Weld area dimension of samples were reduced to $10 \mathrm{~mm}$ to make tensile test. Surface of the machined samples were smoothened. Hardnesses were tested by micro vickers hardness test. Tensile test was applied to the hardness defined samples. Mechanical specifications of used materials were given at Table 1 .

Table 1. Mechanical and physical properties before making the welding process on the St37, St52, AISI304 samples [2].

\begin{tabular}{cccc}
\hline Material & Hardness (5HV) & Thermal conductivity $\mathbf{( W / m K )}$ & Electrical resistance $(\mathbf{\Omega m})$ \\
\hline St37 & 227 & 76 & $0,014 \times 10^{\wedge}-6$ \\
St52 & 269 & 55 & $0,014 \times 10^{\wedge}-6$ \\
AISI304 & 277 & 16,2 & $0,072 \times 10^{\wedge}-6$ \\
\hline
\end{tabular}

\subsection{Welding Process}

36 pieces specimens with $Ø 24 \times 200 \mathrm{~mm}$ dimensions S235JR (St37), S355JR (St52), AISI304 stainless steels have been welded at 851 ampere, 967 ampere, 1102 ampere between each other and in different material combination. Pressing surface of jaws were purged from impurity and rust to prevent contact resistance (Figure 1).

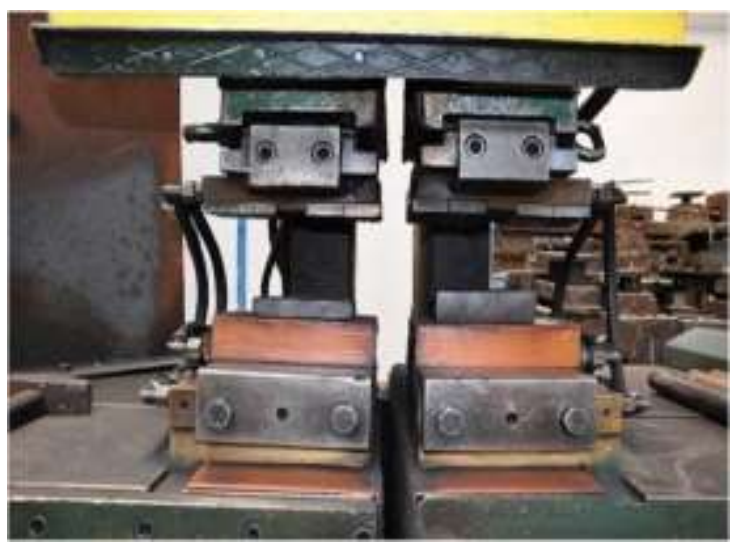

Figure 1.Flash Welding Machine. 


\subsection{Spectrometric Analysis (Chemical Components)}

One for each samples of dimension $\varnothing 24 \times 200 \mathrm{~mm}$ was prepared to use in analysis. Spectrometer

device with 19 elements was used to determine chemical components of metal based sample test. Analysis results were given at Table 2,3,4.

Table 2. Chemical analysis of the S235JR (St37) sample bar.

\begin{tabular}{llllllllll}
\hline \multicolumn{10}{c}{ Chemical analysis of the S235JR (St37) sample bar } \\
\hline $\mathbf{C}$ & $\mathbf{S i}$ & $\mathbf{M n}$ & $\mathbf{P}$ & $\mathbf{S}$ & $\mathbf{C r}$ & $\mathbf{N i}$ & $\mathbf{M o}$ & $\mathbf{A l}$ & $\mathbf{C o}$ \\
\hline$\%$ & $\%$ & $\%$ & $\%$ & $\%$ & $\%$ & $\%$ & $\%$ & $\%$ & $\%$ \\
\hline 0,218 & 0,152 & 0,888 & 0,0151 & 0,0269 & 0,0741 & 0,106 & 0,0142 & 0,0017 & 0,0117 \\
\hline $\mathbf{C u}$ & $\mathbf{N b}$ & $\mathbf{T i}$ & $\mathbf{V}$ & $\mathbf{W}$ & $\mathbf{P b}$ & $\mathbf{S n}$ & $\mathbf{M g}$ & $\mathbf{F e}$ & \\
\hline$\%$ & $\%$ & $\%$ & $\%$ & $\%$ & $\%$ & $\%$ & $\%$ & $\%$ & \\
\hline 0,314 & $<0,0020$ & $<0,00050$ & 0,0011 & $<0,0010$ & 0,0023 & 0,0081 & 0,0013 & 98,2 \\
\hline
\end{tabular}

Table 3. Chemical analysis of the S355JR (St52) sample bar.

\begin{tabular}{llllllllll}
\hline \multicolumn{8}{c}{ Chemical analysis of the S355JR (St52) sample bar } \\
\hline $\mathbf{C}$ & $\mathbf{S i}$ & $\mathbf{M n}$ & $\mathbf{P}$ & $\mathbf{S}$ & $\mathbf{C r}$ & $\mathbf{N i}$ & $\mathbf{M o}$ & $\mathbf{A l}$ & $\mathbf{C o}$ \\
\hline$\%$ & $\%$ & $\%$ & $\%$ & $\%$ & $\%$ & $\%$ & $\%$ & $\%$ & $\%$ \\
\hline 0,625 & 0,165 & 0,706 & 0,0169 & 0,0297 & 0,0788 & 0,0949 & 0,0108 & 0,0027 & 0,011 \\
\hline $\mathbf{C u}$ & $\mathbf{N b}$ & $\mathbf{T i}$ & $\mathbf{V}$ & $\mathbf{W}$ & $\mathbf{P b}$ & $\mathbf{S n}$ & $\mathbf{M g}$ & $\mathbf{F e}$ & \\
\hline$\%$ & $\%$ & $\%$ & $\%$ & $\%$ & $\%$ & $\%$ & $\%$ & $\%$ & \\
\hline 0,27 & $<0,0020$ & $<0,00050$ & 0,001 & $<0,0010$ & 0,0018 & 0,0067 & 0,0014 & 98 \\
\hline
\end{tabular}

Table 4 . Chemical analysis of the AISI 304 sample bar.

\begin{tabular}{llllllllll}
\hline \multicolumn{7}{c}{ Chemical analysis of the AISI 304 sample bar } \\
\hline $\mathbf{C}$ & $\mathbf{S i}$ & $\mathbf{M n}$ & $\mathbf{P}$ & $\mathbf{S}$ & $\mathbf{C r}$ & $\mathbf{N i}$ & $\mathbf{M o}$ & $\mathbf{A l}$ & $\mathbf{C o}$ \\
\hline$\%$ & $\%$ & $\%$ & $\%$ & $\%$ & $\%$ & $\%$ & $\%$ & $\%$ & $\%$ \\
\hline 0,0675 & 0,492 & 1,97 & 0,0467 & 0,0339 & 19,52 & $>60,0$ & 0,364 & 0,0137 & 0,29 \\
\hline $\mathbf{C u}$ & $\mathbf{N b}$ & $\mathbf{T i}$ & $\mathbf{V}$ & $\mathbf{W}$ & $\mathbf{P b}$ & $\mathbf{S n}$ & $\mathbf{M g}$ & $\mathbf{F e}$ & \\
\hline$\%$ & $\%$ & $\%$ & $\%$ & $\%$ & $\%$ & $\%$ & $\%$ & $\%$ \\
\hline 0,692 & 0,017 & 0,0041 & 0,0741 & 0,0536 & 0,0068 & 0,0066 & 0,00048 & 76,3 \\
\hline
\end{tabular}

\subsection{Hardness Measurements}

Micro vickers hardness test was made under the 5 $\mathrm{kg}$ load with J.Amsler \& Co. Schaffhouse-Suisse test device. The average of 6 test results taken from hardness

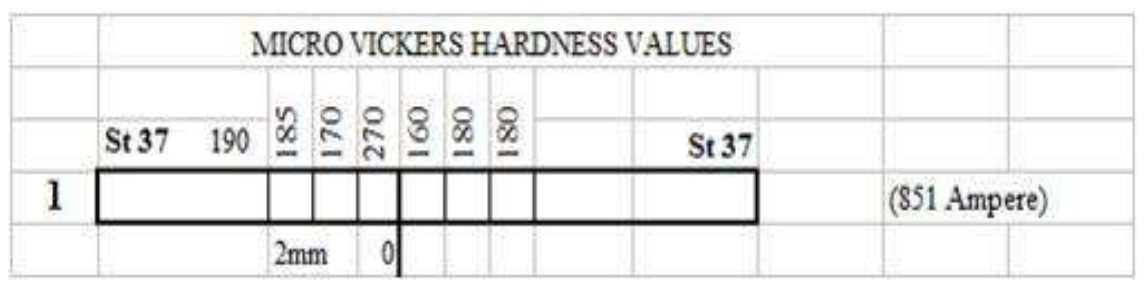

Figure 2. Display on the sample of micro vickers hardness values (0 represents the center of the weld metal). 


\subsection{Tensile Tests}

In this study Mares brand tensile device was used. In the tensile test, samples were exposed to 60 tone load and $30 \mathrm{~mm} / \mathrm{sn}$ tensile speed. For the tensile

test, samples were prepared with dimensions of head diameter $18 \mathrm{~mm}$, thinned part lenght $80 \mathrm{~mm}$, head part lenght $50 \mathrm{~mm}$, total lenght $200 \mathrm{~mm}$ (Figure 3).

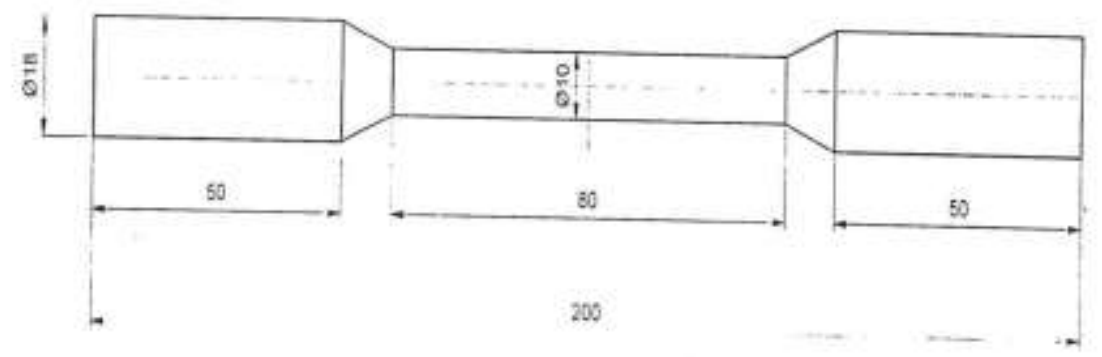

Figure 3. Tensile Sample.

\section{DISCUSSION}

\subsection{Welding Process}

In the weld process minimum accumulation pressure of machine 2 bar, accumulation current 1.8s, seconder current first level 851 ampere, second level 967 ampere, third level 1102 ampere were fixed. Welded samples depicted at figure 4 converted into form as depicted at figure 5 by machining on lathe and 6 samples from eah of them were allocated to use in tensile and hardness tests.

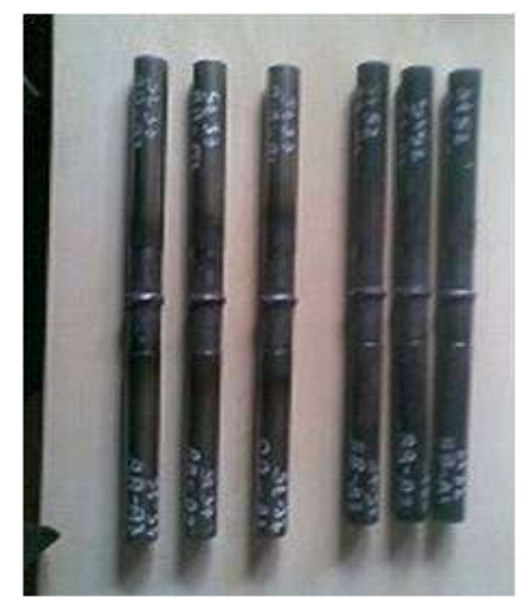

Figure 4. Welded samples.



Figure 5. Welded area of the lathed samples.

\subsection{Hardness Test}

The highest hardness was obtained at welding area at 851 ampere from St37 sample given at figure 6 . The farther away from the welding area to both ends, the more decreased the hardness sharply and increased again. At 967 ampere and 1102 ampere hardness values increased at one end toward welding area then the hardness value became equal to the other end. 


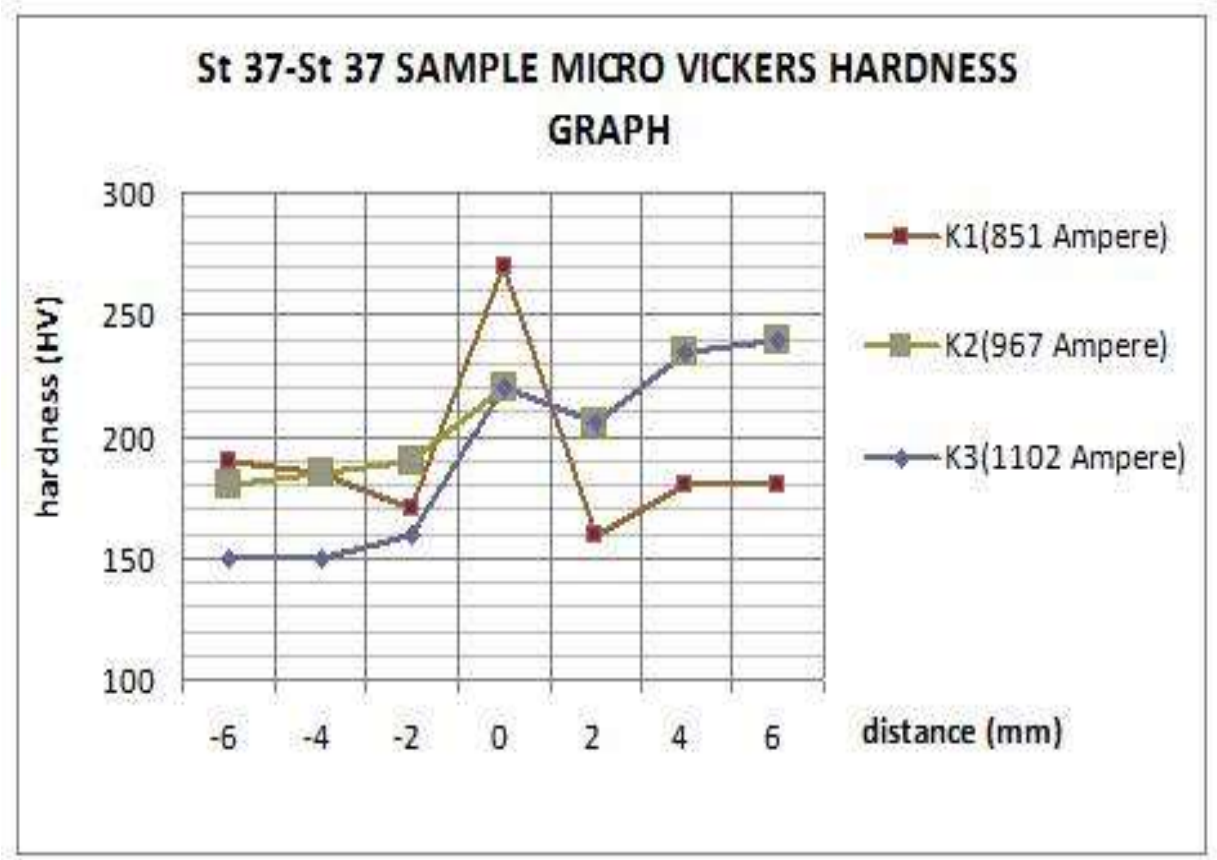

Figure 6. St37-St37 sample micro vickers hardness graph.

Given at the figure 7 in sample St52-St52 at 851 ampere hardness values decreased toward welding area at one end, reached the lowest hardness at welding area and increased at the other end. At 967 ampere hardness values slowly increased toward welding area, after welding area firstly decreased the increased. At 1102 ampere hardness values regularly increased and decreased.



Figure 7. St52-St52 sample micro vickers hardness graph. 
At 851 ampere hardness data of AISI304-AISI304 sample was given at figure 8 shown near values to each other. At 967 ampere hardness value gave the lowest one and increased quickly while go away from welding area. At 1102 ampere hardness value increased to one end and increased to the other.

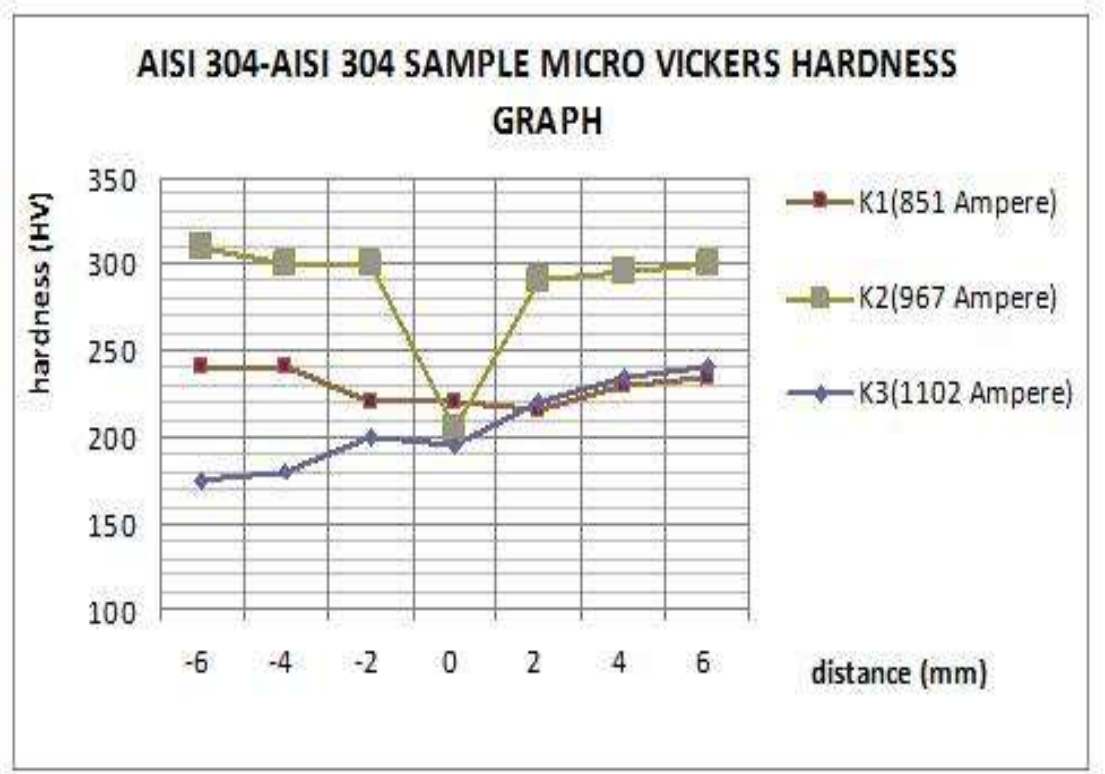

Figure 8. AISI304-AISI304 sample micro vickers hardness graph.

At 851 ampere and 967 ampere for St37-St52 samples were given at figure 9 highest hardness value seen at welding area and sharply decreases seen while go away from welding area. At 1102 hardness values seen near to each other.

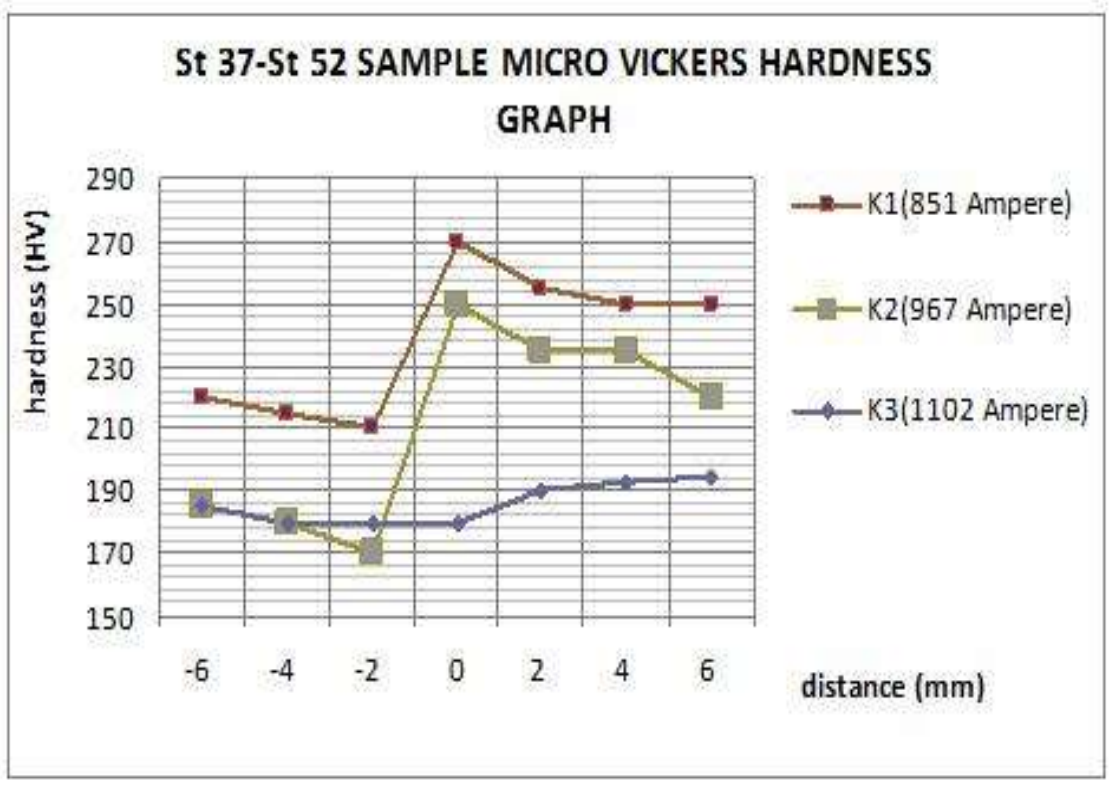

Figure 9. St37-St52 sample micro vickers hardness graph.

At 851 ampere for the sample St37-AISI304 given at the figure 10 hardness value shown lowest one and increased while go away from welding area. At
967 ampere hardness values seen near to each other. At 1102 ampere irregularly increases and decreases were seen. 


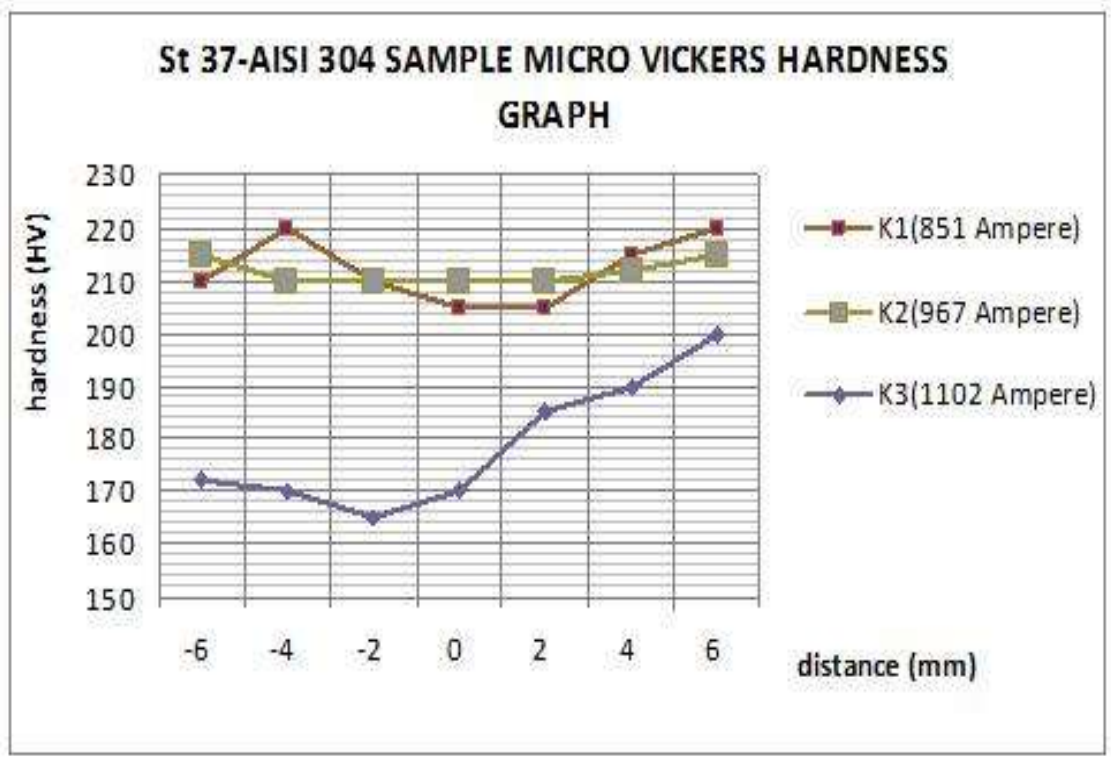

Figure 10. St37-AISI304 sample micro vickers hardness graph.

At 851 ampere for the sample St52-AISI304 given at Figure 11 hardness value was seen lowest one. Hardness values increased while go away from welding area. At 967 ampere irregular increases and decreases were seen. At 1102 ampere hardness value seen near each other at one end toward welding area and shown sharply decreases toward other end.

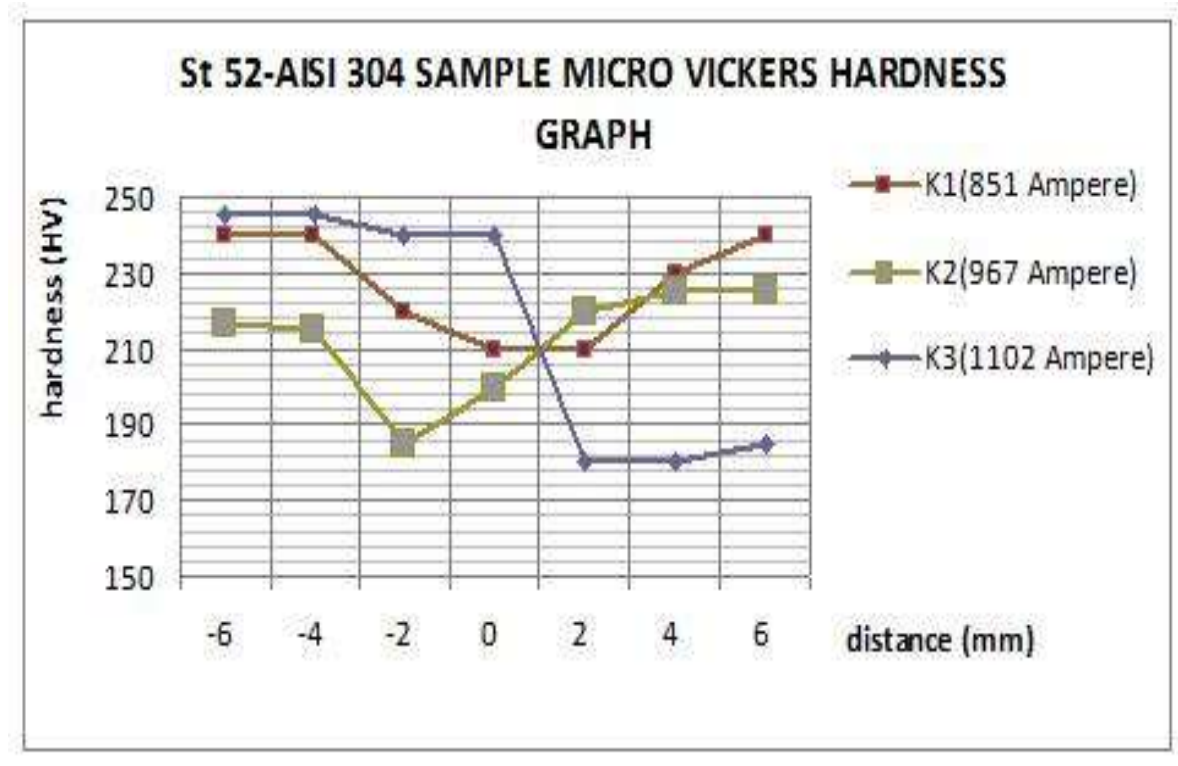

Figure 11. St52-AISI304 sample micro vickers hardness graph.

For the sample St37-St37 given at figure 6, St52St52 given at Figure 7, AISI304-AISI304 given at figure 8 there is no direct effect of change in the welding current to the hardness according to the micro vickers hardness graphics. Highest hardness value seen at St52-St52 sample. As seen in the spectrometric analyze results because of the highest C (carbon) value included in St52 sample this situation covers with the analyze results. Because more increase of $\mathrm{C}$ more increase of hardening ability.

Especialy heat effected excessive change of welding are for sample St37 and St52 was not seen in AISI304 stainless steel. According to the hardness values of sampless, highest one seen approximately 300-350 vickers for the sample 
AISI304-AISI304 given at the figure 8. The reason of highest hardness result seen in the sample AISI304 stainless steel is high quantity of alloyed elements. But because $\mathrm{C}$ (carbon) quantity is very low in the AISI304 stainless steel, hadness change in the welding area and around is lower than change in the welding area taken from St37-St52 samples.

Quick cooling and very high heat of welding area resulted in increase of hardness. While go near from center of welding metal to the main metal generaly hardness values decreased. Also while go toward to the main metal from transition area generaly hardness value increase was seen.

\subsection{Tensile Tests}

When considered the breaking strenght of St37St52, St37-AISI304, St52-AISI304 samples, the highest values were seen at 851 ampere, and with the increase in current decrease in breaking is seen.

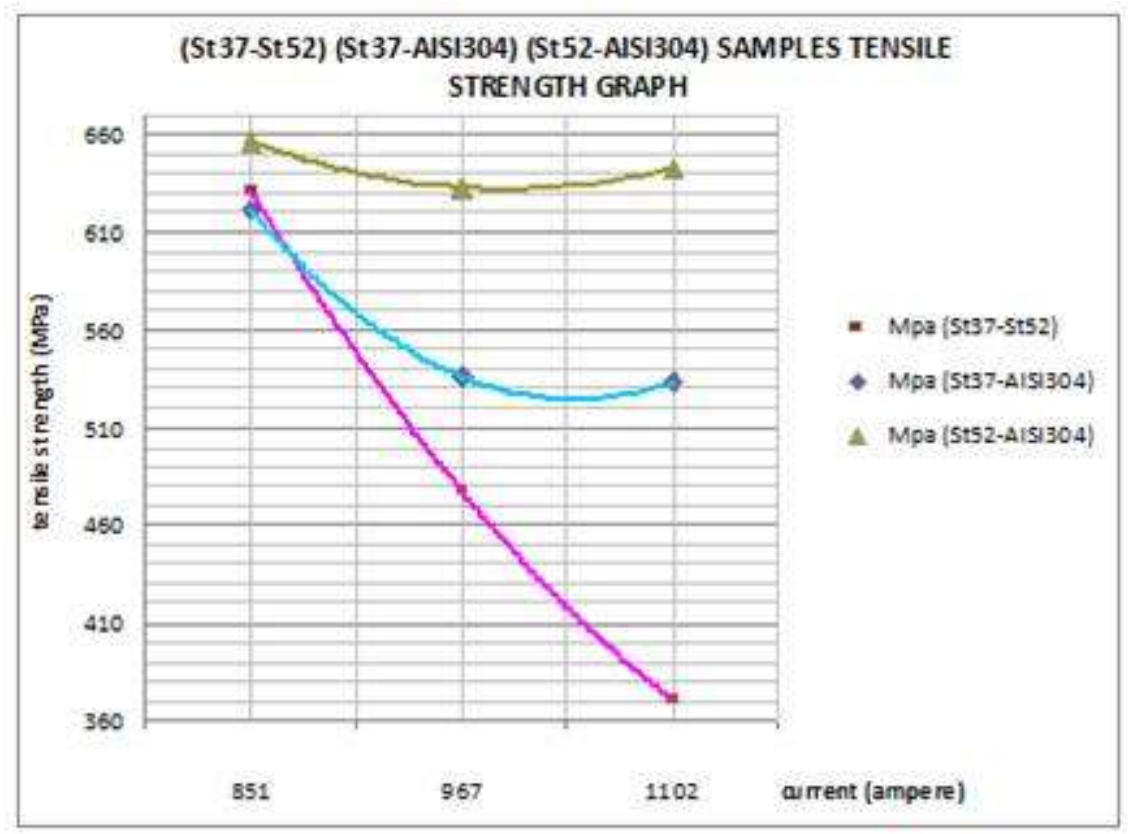

Figure 12. (St37-St52) (St37-AISI304) (St52-AISI304) samples tensile strength graph.

In the samples St37-St37, St52-St52, AISI304AISI304 given at the figure 13 different increases and decreases seen in breaking strenght. In samples St52-St52 and AISI304-AISI304 generaly decrease seen when welding current increase. In St37-St37 generaly very little increas seen in breaking strenght when welding current increase. 


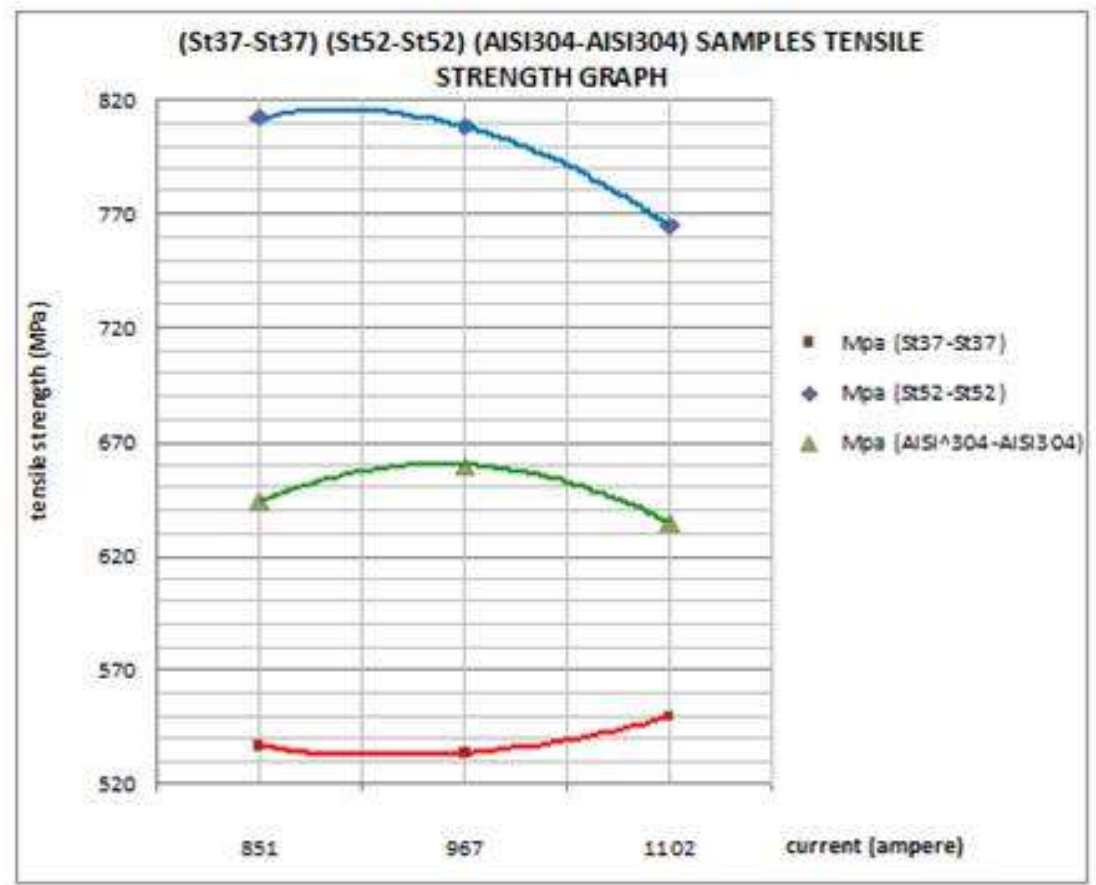

Figure 13. (St37-St37) (St52-St52) (AISI304-AISI304) samples tensile strength graph.

When consider the breaking strenght graphics of AISI304-AISI304, St37-St37 and St37-AISI304 samples it was seen that increase in the welding current generaly effected breaking strenght negatively. This negative effect was seen most in St37-St52 sample. The least effected welded samples by tensile strenght welding current were St37-St37, AISI304-AISI304. Negative decrease in tensile strenght can be seen more clearly especialy when welding curent increase in different combination. Most important reason of this situation is that difficulties occur especialy in fusion welding of different materials. When welding current increase while insufficent fusion occur in one of metals of which physical characteristics are different from each other excessive fusion might occured in another one. It is thought that this effected tensile strenght negatively.

In all samples breaking occured in main materials. It showed that strenght of welding material was higher. Except ITAB none of main materials was effected by welding process and prameters used in tests.
Different studies performed about investigation of mechanic characteristics and integrating by flash welding of different materials. Çetinkaya, have integrated $16 \mathrm{MnCr} 5$ string steel couple to each other by flash welding method and full annealing was applicated to a group of welded samples [3]. In all samples the highest hardness values occured in welding area but with the increasing of accumulation current time decrease was seen in the same area hardness values of none tempered samples. Yilmaz et al.have used the solid state welding techniques and it was seen maximum hardness in welding material in alloyed steel side along the welding line[4] . In the other study, effect of accumulation current time to the welding quality of two different steels (X40CrMoV5 1 (H13), Ç1030 steel couple) welded by flash welding was investigated [5]. In this study it was insisted integration of hot processing tool steel with the low carbon steels. It was found out that quantity of heat applicated to the welding area effected the cooling speed and heat distrubition so change hardness values in welding area. Civelekoğlu made etude of some welding parameters and welding interface in flash welding application to the different metal 
couples ((high speed steel (s-6-5-2) with unalloyed carbon steel) (Ck60)) made by him [6]. He expressed the hardest area seen in welding metal. The integration of S 6-5-2 with 4140 steel by flash welding appliction made the comparision of internal structure was investigated and hardness values obtained from change of some parameters [7]. Consequently approximately $\% 50$ decrease in hardness values after annealing. Another result is that decrease of hardness value was seen with go away from welding area. Yükler, expressed that quantity of heat applied welding area effected cooling speed and heat distribution [8]. Kuroda et al. integrated super dublex stainless steels, $50 \mu \mathrm{m}$ thickness $\mathrm{Zr}$ based $\left(\mathrm{Zr}_{55} \mathrm{Cu}_{30} \mathrm{Ni}_{5} \mathrm{Al}_{10}\right)$ metal and thickness $500 \mu \mathrm{m} \mathrm{Zr}$ metal by flash welding and investigated interior structures [1]. Ghosh, investigated thermal cycle and microstructure of heat effectes zone of flash welded Mn-Cr-Mo dual phase steels [9]. Kuchuk have studied on the flash butt welding applications in pipeline constructions [10]. Thomas et al.have performed an experimental study on the fracture toughness of the flash welded steels [11]. Also, in the other study, the corrosion resistance and weld zone quality of flash butt welded austenitic steels have been investigated [12].

\section{CONCLUSION}

1. It wasn't seen that change in welding current has a direct effect on hardness.

2. The highest hardness value was seen in St52St52 sample. This situation related to the fact that St52 sample has the highest C (carbon) value as seen in spectrometric analysis result.

3. Especialy excessive change in hardness seen in heat effected welding area of St37-St32 samples not seen in AISI304 stainless steel.

4. Regarding the hardness values of samples the highest hardness value was seen approximately 300-350 vickers in AISI304 welded sample. The reason for the highest hardness value seen in AISI304 stainless steel is high quantity of alloyed elements.

5. Even the alloy quantity is high the lowest quantity of C in AISI304 stainless result in less hardening of these samples.

6. Generaly a decrease of hardness value in welding area seen with the increase of current values. Increase of current and current related heat income slowed the cooling speed. So the hardnesses decreased gradually.

7. Very high temperature of welding area and fast cooling resulted in increase of hardness. Values seen from the center of welding metal to the main metal.

8. It was seen generaly increase in welding current negatively effected breaking strenght. This negative effect seen most in St37-St52 sample.

9. Least effected welded samples by tensile strenght welding current were St37-St37, AISI304-AISI304.

10. Especialy negative decrease with the increase welding current in tensile strenght can be seen in different combinations. The biggest reason for this situation is that difficulties of different materials especialy occur in fusion welding.

11. With the increase of welding current, insufficent fusion occur one of metal of which fusion heat and physical characteristics are different while excessive fusion might have occured in one another. It is thought that this effected tensile strenght negatively.

12. Breakings were occcured in main material. It showed that strenght of welding metal was higher.

\section{REFERENCES}

[1]. Kuroda T., Shimada M., "Micro Flash Butt Welding of Super Duplex Stainless Steel with Zr-based Metallic Glass Insert", Joining and Welding Research Institute, Osaka University, 11-1 Mihogaoka, Ibaraki, Osaka, 2008, 5670047, Japan.

[2]. Kutay M.G., "Mukavemet Değerleri Formüller ve Tablolar", 2009.

[3]. Çetinkaya C. ve Arabacı U., "Yakma Alın Kaynağ 1 ile Birleştirilen 16MnCr5 Zincir Çeliğinde Yığma Akım Zamanı ve Tam Tavlama Isı1 İşleminin Mekanik Özelliklere Etkisinin İncelenmesi”, Metal Eğitimi Bölümü, Teknik Eğitim Fakültesi, Gazi Üniversitesi, 06500, Teknikokullar, Ankara Gazi Üniv. Müh. Mim. Fak. Der. Cilt 19, No 4, 2004, 455-465.

[4]. Yılmaz M., Karagöz Ş., "Katı Hal Kaynağında Mikro Analiz Uygulamas1, XI. Ulusal Elektron Mikroskopisi Sempozyumu", Edirne,1993, 163165.

[5]. Çetinkaya C., Arabacı U. ve Akay A., "Yakma Alın Kaynağı ile Kaynatılmış İki Farklı Çeliğin Kaynak Kalitesine Yığma Akım Zamanının Etkisi”, Metal Ĕ̆itimi Bölümü, 
Teknik Eğitim Fakültesi, Gazi Üniversitesi, 06500, Teknikokullar, Ankara Gazi Üniv. Müh. Mim. Fak. Der. Cilt 21, No 3, 2006, 519525.

[6]. Civelekoğlu F., "Yüksek Hız Çeliği [S-6-52] ile Alaşımsız Karbon Çeliği [Ck60] Çubuklarının Yakma Alın Kaynağı ile Birleştirilmesinde Bazı Kaynak Parametrelerinin ve Kaynak Ara Yüzeyinin Etüdü’, Doçentlik Tezi, İTÜ, İstanbul, 1971, 7-59.

[7]. Yumurtac1 S., Sönmez N., Karaaslan A., Aslan U., "S 6-5-2 ile 4140 Çeliğinin Yakma Alın Kaynağı Yöntemi ile Birleştirilmesi", Y.T.Ü Müh. Fak. Mak. Müh. Bölümü, TMMOB Makine Mühendisleri Odası Kaynak Teknolojisi III. Ulusal Kongresi Bildiriler Kitabl, Ekim 2001 Yayın No: E/2001/277.

[8]. Yükler A.İ., “Kaynak Metali”, Erdini Basımevi, İstanbul,1979, 17-60.

[9]. Ghosh P.K., "Thermal cycle and microstructure of Heat Effected Zone of flash butt welded Mn-Cr_Mo Dual phase steel", ISIJ International., V. 30, N. 4, 1990, pp. 317-324.
[10].Kuchuk S., "Experince of Flash Butt Welding Application in Pipeline Consruction in the USSR", Proceeding of Pipeline Technology Conferenc,. Ostend, Belgium, 1990, pp. 3739.

[11].Thomas K., Michailov, V., Wohlfahrt, H., "Toughness Investigation on Narrow Process - Affected Zones Resistance Butt", Welding and Cutting, V.52, 2000, pp. 254-262.

[12].Kalvala P., Rao K., Kannurpatti N., "Effect of Welding Parameters on the Quality and Corrosion Characteristic of Flash Butt Welded Austenitic Steels", Schweissen Und Schneiden., V. 42, N.1, 1990, pp. 4-6.

[13].Zhang F., Lv B., Hu B., Li Y., "Flash Butt Welding of High Magnase Steel Crossing and Carbon Steel Rail", State Key Laboratory of Metastable Materials Science and Technology, College of Materials Science and Engineering, Yanshan University, Qinhuangdao 0660044, China, 2006. 